\title{
EXPLANATION OF TABLES
}

Tables 1 to 20 were prepared from the verbatim translations of material taken from the 1973 editions of these books:

USA-Physicians' Desk Reference

Mexico-Diccionario de Especialidades Farmacéuticas,

Edición Mexicana

Central America and Dominican Republic-Ibid., Edición

C.A.D.

Ecuador and Colombia-Ibid., Edición E. Co.

BrazIL-Index Terapêutico Moderno

Argentina-Therapia Vademecum

(Note: Except for Argentina, the descriptive material in these books comes from the pharmaceutical companies. In Argentina, the companies have no responsibility for the published statements.)

In each instance, a check mark shows that the indication for use, contraindication and warning, or adverse reaction is included in the drug description for the countries concerned. Special note is made where no hazards are disclosed in the description.

The promotional material considered here may or may not be the same as that included in package inserts, miscellaneous company literature, or information presented orally by detail men. The 1973 descriptions do not necessarily correspond to statements made in 1975. 
